\title{
Absorptive Capacity in Optimum Internal Utilization of Foreign Direct Investment in Pakistan
}

\author{
Sohail Farooq ${ }^{1}$ \\ Ijaz Ahmad' \\ Muhammad Akram Gilal ${ }^{3}$ \\ Abdul Rahman Nizamani ${ }^{4}$
}

\begin{abstract}
This paper examined the effect of Absorptive Capacity (ABC) on Foreign Direct Investment (FDI) in optimum internal utilization using Auto Regressive Distributed Lag Approach (ARDL). The results reveal the relevancy of human capital, patent application, electricity consumption, inflation, number of Doctor of Philosophy (Ph.D.), and trademark as determinants of FDI in Pakistan. In long run FDI is determined by human capital, patent right application, number of PhDs, electric power consumption, inflation, and trademark application while in short run lagged inflation and lagged trademark applications are the relevant arguments. An increase in human capital, patent application, and electricity consumption augments growth process of Pakistan, whereas a rise in the number of PhDs and trademark application retards growth process. Based on empirical evidence, it is recommended that the relevant authorities should formulate policies that augment factors causing FDI inflows and control those that retard it.
\end{abstract}

JEL Classification: E22, E31, J24, O34.

Keywords: Absorptive capacity, foreign direct investment, Stationary.

\section{INTRODUCTION}

FDI refers to long-term investment made by residents of foreign countries in a host country. It results in the transfer of technology, managerial skills and improvement in production techniques. FDI can be horizontal or vertical, horizontal FDI takes place when multinational companies' start same production techniques and activities in multiple countries and is driven by market seeking motives. Whereas Vertical FDI, on the other hand, refers to multinational company investing in a foreign firm doing the same kind of business that multinational operates domestically. FDI inflows to a majority of countries are vertical in nature due to lack of well-established markets and institutions and are driven by rent or efficiency seeking motives

FDI has been considered an engine of economic growth for developing economies (Borensztein, De Gregorio and Lee, 1998; De Mello 1999; Chandana and Parantap 2002; Liu et al. 2002; Akinlo 2004; Eller, Haiss and Steiner, 2005; Moses 2011; Tintin 2012; Hussain and Haque 2016; Choi and Baek 2017; Ridzuan, Ismail and Hamat (2017) and has potential to generate employment opportunities, increase productivity, transfers latest managerial skills and modern technology, promote exports and contribute to host country economic development. It acts as a medium for transforming and mobilizing real and intangible resources and can result in economic growth of the country beyond imagination (Bosworth and Collins, 1999).

1- Hazara University Mansehra Pakistan

2- Hazara University Mansehra Pakistan

3- University of Sindh, Jamshoro Pakistan E-mail akram.gilal@usindh.edu.pk

4- University of Sindh, Jamshoro Pakistan

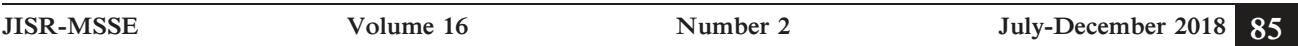


Since its inception, Pakistan has been faced with social and economic problems that have worsened over time. Economic issues that hamper economic growth of the country and need to be tackled on priority basis include lack of technical and managerial skills, poor infrastructure, high inflation, low literacy level, low research and development (R\&D) investment, high poverty, lack of industrialization, rapidly increasing population, and external debts (Government of Pakistan, 2015). Insufficient supply of domestic resources makes it necessary for the country to attract FDI in sufficient amount to address these issues.

Figure 1.1 shows that Pakistan has remained an important destination for FDI inflows over a time. However, the country share in Global FDI has remained volatile and reached its lowest level in 2000 followed by ups and downs in subsequent years.

Figure 1 Pakistan's share in World FDI, net inflows (Balance of Payment, Current US \$).

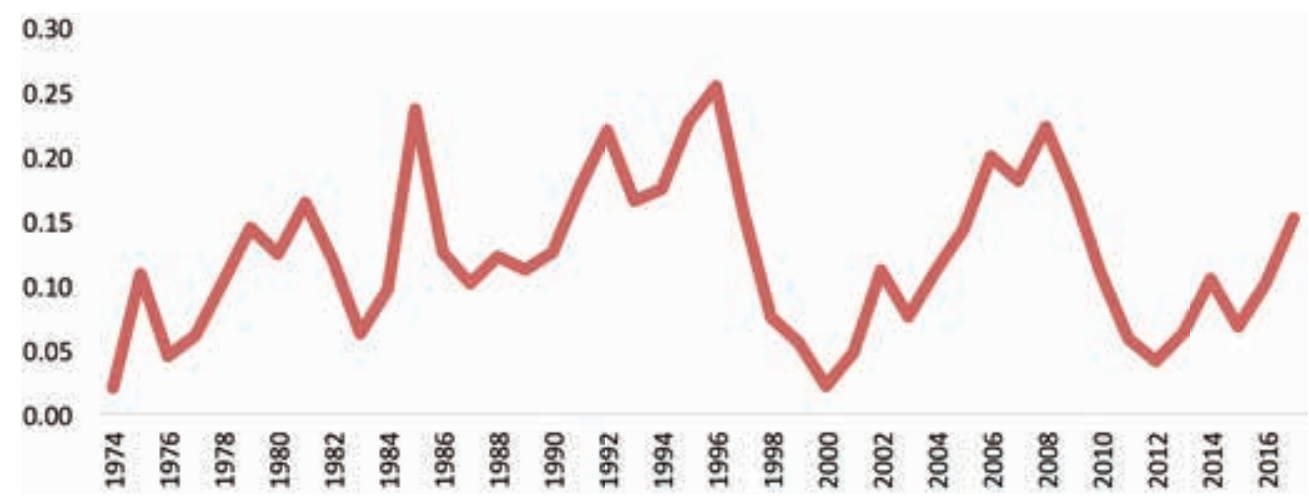

Country absorptive capacity is one of many factors that attract FDI (Agiomirgianakis, Asteriou, and Papathoma, 2003). Due to its importance, every country tries to attract FDI to its maximum level (United Nation Conference on Trade and Development, 1998). However, with few exceptions, most of the countries have miserably failed in attracting FDI in the required amount. Figures show that four countries namely China, Hong Kong, Netherland and the United States of America attracted more than 50 percent of world FDI, 17 countries attracted FDI between one and five percent and the remaining 20 percent of World's net FDI was shared by 97 countries (WDI, 2018). This raises the question what factors determine FDI inflows to a particular destination?

FDI results in economic growth due to technological innovation, known as $\mathrm{ABC}$ because its availability in required amount helps firms' embrace new knowledge (Girma, 2005; Blalock \& Gertler, 2009; Shamsub, 2014). Despite its importance, the earlier empirical literature on determinants of FDI in Pakistan has not given proper attention to ABC as its determinant (see Iqbal and Ahmad, 2014; Khan and Khan, 2011; and Shahbaz et al., 2011). This study bridges that gap and examines the effect of ABC in attracting FDI in Pakistan using time series data from 1973 to 2014 and ARDL model.

The remaining paper proceeds as: in section 2 past studies evaluating the effect of ABC on FDI are reviewed, followed by a discussion on data and its sources in section 3 . Detailed discussion on the model is given in section 4 followed by methodology and results in section 5 . Section 6 concludes.

86 July-December $2018 \quad$ Volume $16 \quad$ Number $2 \quad$ JISR-MSSE




\section{LITERATURE REVIEW}

$\mathrm{ABC}$ is a broader concept and is considered moderator of productivity and growth. ABC and economic development have non-linear relationship and benefits generated from a marginal increase in $\mathrm{ABC}$ vary over a time. It is argued that in order to achieve higher growth, countries or firms must be capable of absorbing, internalizing and utilizing available knowledge. Human capital in sufficient supply generates new knowledge or technologies and translate them into productivity growth. Capacity to absorb external knowledge or technology is determined by the country's stage of economic development. It acts as a catalyst in mobilizing technology flow. FDI, intermediate goods and capital equipment do personify technology flows and in absence of ABC they have no or minimal effect on growth of the country.

FDI and knowledge transfer are positively associated with the growth of the recipient country (Khordagui and Saleh, 2016). However, majority of earlier empirical literature using sectoral level panel and time series data found that Emerging and Middle Eastern Economies failed in taking advantage of FDI due to their insufficient attention on $\mathrm{ABC}$ as a determinant of these flows. These studies use human capital as a proxy for ABC. Contrary to these studies, Farole and Winkler (2015) found $\mathrm{ABC}$ as a major determinant of extent and direction of spillover effects of FDI on local firm productivity in 78 low- and middle-income countries. Kim, Lee, and Lee (2015) show that ABC mitigates negative spillover effects of FDI by capturing its positive effects in the South Korean manufacturing sector. However, ABC appears insignificant in alleviating negative spillover effect, once endogeneity arising from ABC such as R\&D was considered. FDI does not affect income distribution in absence of ABC in the required level (Wu and $\mathrm{Hsu}, 2012)$. Hence lack of host country capacity utilization discourages FDI and is therefore harmful for fair distribution of income.

Kinishita \& Lu (2006) show that insufficient and low-quality infrastructure acts as a deterrent to FDI and stagnate economy despite demand for technology consumption. Krogstrup and Matar (2005) using four features of ABC such as (a) financial development, (b) quality of institutions, (c) workforce education, and (d) technology gap found their significant effect on FDI. Girma \& Gorg (2005) calculated ABC as the technology gap in terms of Total Factor Productivity (TFP) between domestic establishment and industry leader. Using the UK data and allowing non-linear relationship, they found that $\mathrm{ABC}$ is an important factor that determines whether a domestic establishment can benefit from FDI or not.

Bloomstrm and Kokko (2003) show that the level of human capital determines FDI and transfer of technology. Hence countries with strong human capital base attract large FDI and transfer of technology. Berg (2001) noted that quality of labor, their level of experience and education system determine host country capacity to create space for new ideas and adapt old ones. Hence quality education system and strong human capital are essentials for absorbing and adapting foreign technology for attaining sustainable long-run economic growth. Moreover, he illustrates that FDI and human capital interact with each other in complex manners, foreign inflows create the potential for knowledge spill over to the host country's labor force. Human capital, on the other hand, determines domestic firms' extent to absorb potential benefits of FDI. The study concludes that a sufficient level of human capital attracts technology intensive FDI which in turn enhance labor productivity. Noorbakhsh, Paloni, and Yousif (2001) found a positive link between human capital and FDI for developing economies. Kinoshita (2000) argued that there are two channels through which R\&D affects productivity growth. First, it directly increases the technology level by adding new

\begin{tabular}{llll}
\hline JISR-MSSE & Volume 16 & Number 2 & July-December 2018 \\
\hline 87
\end{tabular}


information. The second R\&D enhances the ABC of the firm. Based on empirical evidence from Czech Republic manufacturing firms, he concludes that FDI recipient must have the ability to absorb, internalize and adopt the technology. Further, R\&D activities help in increasing technology spill over by enhancing the firm's ABC. De Gregorio and Lee (1998) using human capital as a proxy for $\mathrm{ABC}$ show that sufficient availability of human capital results in a positive association between FDI and economic growth of the host country. Borensztein, De Gregorio and Lee (1998) conclude that FDI is an important tool for the transfer of technology and contributes more to economic growth than domestic investment. However, productivity spillover of these inflows is conditioned with host country stock of human capital. Using human capital as a proxy for ABC for 69 developing countries they suggest that introduction of more advanced technology and ABC of host economy determine its economic growth. According to Romer (1990), human capital instead of population size determines the economic growth of the country on a sustainable basis. Countries having a strong human capital stock experience faster growth than those with unskilled human capital.

\section{Data}

Time series data from 1973 to 2014 for Pakistan is used for conducting regression analysis. The data is taken from World Bank World Development Indicators, The Global Economy of Pakistan, United Nations Conference on Trade and Development (UNCTAD), International Monetary Fund International Financial Statistics, and Bureau of Statistics Pakistan. Data on the number of PhDs in Pakistan is taken from the Higher Education Commission of Pakistan Annual Report (2013-14). All variables are used in log form. It enables us to interpret estimated parameters in terms of elasticities (Ajmair, Gilal, Farooq and Hussain 2018).

\section{Model}

Asiedu (2006) examined the role of natural resources, market size, government policy, institutions and political instability in attracting FDI for Sub Saharan African countries. Asiedu (2006) approach is augmented for examining the interaction between ABC and FDI inflows. The equation estimated in this paper is given as:

$$
\begin{aligned}
& \Delta f d i_{t}=\beta_{0}+\sum_{i=1}^{p} \beta_{1} \Delta f d i_{t-i}+\sum_{i=1}^{p} \beta_{2} \Delta h c_{t-i}+\sum_{i=1}^{p} \beta_{3} \Delta p a r_{t-i}+\sum_{i=1}^{p} \beta_{4} \Delta p h d s_{t-i}+\sum_{i=1}^{p} \beta_{5} \Delta e p c_{t-i}+\sum_{i=1}^{p} \beta_{6} \Delta \inf _{t-i} \\
& \sum_{i=1}^{p} \beta_{7} \Delta t m r_{t-i}+\beta_{8} f d i_{t-1}+\beta_{9} h c_{t-1}+\beta_{10} p a r_{t-1}+\beta_{11} p h d s_{t-1}+\beta_{12} e p c_{t-1}+\beta_{13} \inf _{t-1}+\beta_{14} t m r_{t-1}+\varepsilon_{t}
\end{aligned}
$$

Where $f d i_{\mathrm{t}}=$ foreign direct investment, $h c_{\mathrm{t}}=$ human capital index, par $_{\mathrm{t}}=$ patent application by residents, $p h d s_{\mathrm{t}}=$ number of Doctor of Philosophy, $e p c_{\mathrm{t}}=$ electricity consumption, inf $_{\mathrm{t}}=$ growth in consumer price index (a proxy for inflation) and $t m r_{\mathrm{t}}=$ trademark application by residents. $\Delta$ represents difference operator $\varepsilon_{\mathrm{t}}$. is stochastic disturbance which is normally distributed with zero mean and constant variance. $\beta_{1}$ to $\beta_{7}$ represent short-run dynamics of the model and $\beta_{8}$ to $\beta_{14}$ our long-run estimates of slope parameters. Null hypothesis tested is:

$$
\begin{aligned}
& H_{0}: \beta_{8}, \beta_{9}, \beta_{10}, \beta_{11}, \beta_{12}, \beta_{13}, \beta_{14}=0 \text { against alternative hypothesis } \\
& H_{a}: \beta_{8} \neq \beta_{9} \neq \beta_{10} \neq \beta_{11} \neq \beta_{12} \neq \beta_{13} \neq \beta_{14} \neq 0
\end{aligned}
$$


Wald or F-statistic is used for testing the presence of long-run cointegrating vector among the variables. Null of no cointegration among the variables is rejected if calculated statistics exceed it upper bound critical values. Null of no cointegration cannot be rejected if calculated F-statistics is lower than the lower bound critical value and results remain inconclusive if calculated F-statistics fall between upper and lower bound critical values.

Following relevant literature on the determinants of FDI, this study uses four features of ABC and they include (a) human capital index (An index showing capacity of skilled and experienced individuals or population in terms of their value or cost to an organization or country), (b) patent applications (A system throughout the world, where people patent their inventions: a product or a process that provides a new way of doing something and this patenting is usually done by patent corporation or national patent office), (c) number of $\mathrm{PhDs}$ produced per year) and (d) Trade Mark Applications by residents (Trademark is a distinctive sign that identifies specific good or services by an individual or enterprise). Human capital refers to an embodiment of knowledge of country labor force and is acquired through schooling (Dorozynska and Dorozynska, 2014). It enhances the nation's ability to absorb and initiate technology and result in more capital inflows in the country (Barro and Salai-i-Martin). Patent right (PR) is part of infrastructure investment in research and development (R\&D). PRs are important for research and innovation and grant the right holder to sell their product on price above marginal to recover initial expenditures incurred on research and innovation. Effective implementation of patent rights influence firms' business location decision and market structure. Hence effective implementation of patent rights affect FDI inflows in the country positively (Hsu and Tiao Yu-En, 2015). According to Markusen (1995), multinationals prefer firms and industries having research and development larger than sales, technical and professional labor force, new and complex products, and product differentiation. Since doctorate is the highest professional degree and it is expected that the economies having a large number of doctorates will attract FDI in large amount. Electricity consumption affects FDI through economic growth. Inadequate energy supply results in the low manufacturing output which retards FDI inflows. Hence positive association between energy consumption and FDI inflows is expected. A rising inflation represents macroeconomic uncertainty distort economic activities and leads to lesser inflows of FDI in the country (Khan and Mitra, 2014). Hence the effect of inflation on FDI is negative. Trademarks are component of intellectual property rights. Inadequate protection of intellectual property rights makes the investment in research and development less attractive thus affect global economic growth and international trade. Multinational corporations do not consider the location where intellectual property rights are not strictly implemented in their investment decisions (Seyoum, 1996). Since all these factors except inflation enhance country/firms capacity to absorb FDI and associated knowledge transfer, hence any improvement in these variables will attract FDI in the country. Electric power consumption per capita is used for available infrastructure in the country. It is argued that FDI is associated with development of major sectors of the country economy. Hence in order to achieve such benefit of FDI availability of electricity in sufficient level is inevitable. Hence a positive association between electricity consumption per capita and FDI inflows is expected here (Alam, 2013). High inflation is associated with macroeconomic uncertainty. An increase in inflation distort investors' perception and have a negative effect on the profitability of future investment projects. Hence the negative effect of inflation on FDI is expected (Erramilli and D'Souza, 1995) 


\section{EMPIRICAL ANNALYSIS AND FINDINGS}

ARDL approach is employed for evaluating the interaction between FDI and its covariates for Pakistan. Contrary to Engle and Granger (1987), Johansen (1991) and Phillips and Hansen (1990), Pesaran, Smith, and Shin (2001), ARDL does not require testing integrating order of variables, perform better in small samples and estimates short run and long run relationship simultaneously. Although ARDL does not require to test cointegrating order of the variables, still it is important to do so to make sure none of the variables is $I(2)$ because critical F-statistic was given by Pesaran, Smith, and Shin (2001) become invalid if some of the variables are I(2) or beyond (Oyakhilomen and Zibah, 2014).

Table 5.1

ADF Test.

\begin{tabular}{llllll}
\hline Variables & \multicolumn{3}{c}{ Intercept } & \multicolumn{3}{c}{ Intercept and Trend } & Outcome \\
\hline & Level & 1st Difference & Level & 1st Difference & \\
\hline$f d i_{\mathrm{t}}$ & -2.07 & $-5.85 * * *$ & -2.75 & $-5.89 * * *$ & $\mathrm{I}(1)$ \\
phds $_{\mathrm{t}}$ & -3.67 & -- & $-4.69 * * *$ & -- & $\mathrm{I}(0)$ \\
par $_{\mathrm{t}}$ & 0.125 & $-6.29 * * *$ & -1.60 & $-6.57 * * *$ & $\mathrm{I}(1)$ \\
$h c_{\mathrm{t}}$ & -1.92 & $-1.72 * *$ & -2.94 & $-3.84 * *$ & $\mathrm{I}(1)$ \\
$t m r_{\mathrm{t}}$ & -0.27 & $-9.39 * * *$ & -4.73 & $-9.26 * * *$ & $\mathrm{I}(1)$ \\
$e p c_{\mathrm{t}}$ & -2.80 & $-4.54 * * *$ & 0.19 & $-5.33 * * *$ & $\mathrm{I}(1)$ \\
$i n f_{\mathrm{t}}$ & $-2.97 * *$ & - & $-3.87 * *$ & - & $\mathrm{I}(0)$ \\
\hline
\end{tabular}

Note: $* * *, * *$, and $*$ indicates the rejection of Null hypothesis at 1\%, 5\% and $10 \%$ level of significance respectively. Critical values are MacKinnon (1996) one-sided p-values.

ADF test that has been widely used in empirical literature to test integrating order of variables is also applied here for testing time series properties of the variables. Results given in table 5.1 indicate that $f d i_{\mathrm{t}}, p a r_{\mathrm{t}}, h c_{\mathrm{t}}, t m r_{\mathrm{t}}$ and $e p c_{\mathrm{t}}$ are nonstationary in level and stationary at first difference, whereas inft and phdst are level stationarity. Since none of the variables is second difference stationary hence using ARDL for examining the importance of $\mathrm{ABC}$ in attracting FDI in the country is valid.

ARDL is sensitive to lag length hence information criterion was estimated for selecting an optimal lag length for estimating equation (4.1) using ARDL approach. Based on the Akaike Information Criterion, two lags were used for estimating the equation. Table 5.2 shows that calculated F-statistic exceed upper bound one, five and ten percent critical values hence null of no cointegration among the variables is rejected.

Table 5.2

F-statistic of Cointegration Relationship.

\begin{tabular}{lcc}
\hline Significance level & Calculated F Statistic 6.609984 \\
\hline & Lower Bound & Upper Bound \\
\hline 1 percent & 2.88 & 3.99 \\
2.5 percent & 2.55 & 3.61 \\
5 percent & 2.27 & 3.82 \\
10 percent & 1.99 & 2.94 \\
\hline
\end{tabular}


Results of the normalized cointegrating vector are given in table 5.3. It is clear from the table that in the long run human capital, patent right application, electricity power consumption and inflation have a significant positive effect on FDI. However, the number of Doctor of Philosophy and trademark application effect on FDI in long run is negative.

Table 5.3

Estimates of Long Run Cointegrating Vector.

\begin{tabular}{lcc}
\hline Regressor & Coefficients & T-Statistics \\
\hline $\mathrm{C}$ & -4.575 & $-5.364^{a}$ \\
$h c_{\mathrm{t}}$ & 3.628 & $2.007^{a}$ \\
par $_{\mathrm{t}}$ & 0.536 & $2.722^{a}$ \\
phd $_{\mathrm{t}}$ & -0.404 & $-2.132^{a}$ \\
$e p c_{\mathrm{t}}$ & 2.459 & $6.372^{a}$ \\
$i n f_{\mathrm{t}}$ & 0.514 & $4.991^{a}$ \\
$t m r_{\mathrm{t}}$ & -1.103 & $-3.138^{a}$ \\
\hline
\end{tabular}

Note: superscript a shows estimated parameters significance at 5 percent significance level.

Table 5.4

Error Correction Representation of ARDL Model.

\begin{tabular}{lcc}
\hline Regressor & Coefficients & T-statistic \\
\hline$\Delta f d i_{\mathrm{t}-1}$ & 0.934 & $6.549^{a}$ \\
$\Delta f d i_{\mathrm{t}-2}$ & 0.323 & $2.755^{a}$ \\
$\Delta f d i_{\mathrm{t}-3}$ & 0.573 & $4.610^{a}$ \\
$\Delta i n f_{\mathrm{t}}$ & 0.267 & $2.239^{a}$ \\
$\Delta i n f_{\mathrm{t}-1}$ & -0.441 & $-3.412^{a}$ \\
$\Delta t m r_{\mathrm{t}-1}$ & 0.710 & $2.241^{a}$ \\
$e c t_{\mathrm{t}-1}$ & -1.635 & $-8.329^{a}$
\end{tabular}

Note: superscript a shows significance of estimated parameters at 5 percent significance level.

Short run estimates of equation 4.1 are given in table 5.4. It reveals that current FDI is positively affected by its own up to three lags which may show persistence in country's FID inflows. Current and lagged inflation have a positive and negative effect on FDI inflows. Contrary to the long run, the short run estimate of the trademark application is significant and positively signed emphasizing the importance of trademark application in attracting FDI in the country. Error correction term show deviation of FDI from its equilibrium level. Its estimate is significant and negatively signed and its more than unity value suggest the speedy adjustment of deviation of FDI towards its long-run equilibrium.

Table 5.5

Residual Properties.

\begin{tabular}{llll}
\hline$R^{2}$ & 0.81 & $L M_{\text {Test }}$ & $0.78(0.47$ \\
$\bar{R}^{2}$ & 0.63 & F-Stat Hetr & $0.26(0.62)$ \\
F-Stat & $4.79(0.00)$ & White $_{\text {Hetr }}$ & $0.62(0.84)$ \\
DW test & 2.00 & $J B_{\text {Norm }}$ & $3.37(0.19)$ \\
\hline
\end{tabular}

Note: LM test is the Breusch-Godfrey test. Hetr and ARCH refer to heteroscedasticity and autoregressive conditional heteroscedasticity tests respectively. Values in parentheses are probability values of obtaining these test statistics.

\begin{tabular}{llll}
\hline JISR-MSSE & Volume 16 & Number 2 & July-December 2018 \\
91
\end{tabular}


Diagnostic tests are given in table 5.5. It indicates that residuals are normally distributed and do not suffer from autocorrelation and heteroscedasticity issues. Since the residuals satisfy their properties, hence it can be concluded that the estimated model is well fitted. Further, the cumulative sum of recursive residuals and the cumulative sum of recursive residuals square test statistics are used for testing the model stability. Null of

Figure 5.1 Cumulative Sum of Recursive Residuals.

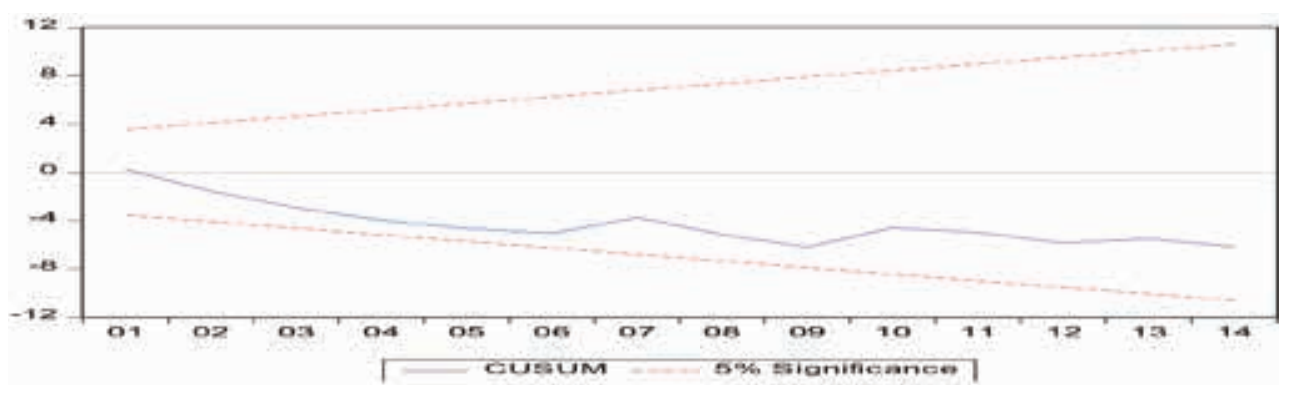

Figure 5.2 Cumulative Sum of Recursive Residuals Square.

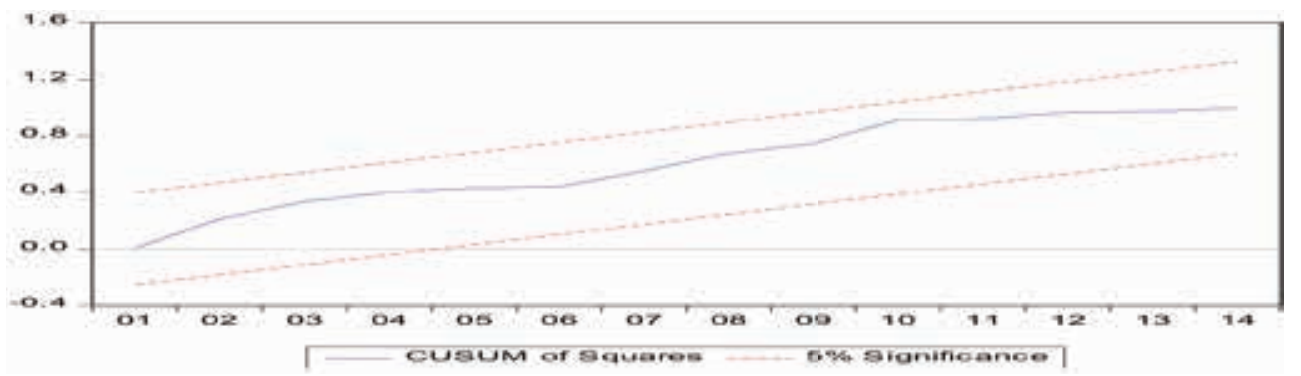

stability is not rejected if cumulative sum does not cross critical bounds. It is evident from figure 5.1 and 5.2 that the estimated cumulative sum of recursive residuals and the cumulative sum of recursive residuals square do not cross their upper and lower bound critical limits implying stability of long and short run estimated model. Hence the model estimated in this paper does not suffer any structural breaks and is stable, therefore.

\section{CONCLUSION}

In this paper, we evaluated the effect of $\mathrm{ABC}$ in attracting FDI in the country. ABC was proxied with a number of $\mathrm{PhDs}$, patent application, trademark applications, and human capital index. Other variables used as determinants of FDI were inflation and electricity power consumption. ARDL estimation procedure covering the time span 1973 to 2014 was used for estimating the interaction among these variables.

Results indicate nonstationarity of all the variables in level and stationarity at first difference. Cointegration results reveal that in long run human capital, patent right application, number of PhDs, electric power consumption, inflation and trademark application are the relevant determinants of FDI in the country. Short run estimates indicate persistence in FDI inflows. 
Current and lagged inflation attract and augment foreign investment while lagged trademark application has a positive association with FDI inflows.

On the basis of the above findings, it is recommended that government should focus on developing human capital and ensure application of patent rights if it wants to attract FDI for sustainable economic growth. Further, it should also focus on the provision of uninterrupted power supply and allow a gradual increase in prices for augmenting FDI. This will help in the absorption and utilization of FDI and will increase employment opportunities in long run. Hence the government and policymakers must formulate a policy framework and build human capital if they want to attract large FDI inflows in the country.

\section{REFERENCES}

Agiomirgianakis, G., Asteriou, D., \& Papathoma, K. (2003). The Determinants of Foreign Direct Investment: A Panel Data Study for the OECD Countries. Working Papers 03/06, Department of Economics, City University London

Ajmair, M., Gilal, M.A., Farooq, S., \& Hussain, K. (2018). Factors determining growth in Pakistan: An ARDL bound testing. Pakistan Journal of Applied Economics, 28(2) (forthcoming)

Akinlo, A.E. (2004). Foreign direct investment and economic growth in Nigeria: An empirical investigation. Journal of Policy Modeling, 26, 627-39.

Alam, A. (2013). Electric power consumption, foreign direct investment, and economic growth. World Journal of Science, Technology and Sustainable Development, 10(1), $55-65$.

Asiedu, E. (2006). Foreign direct investment in Africa: The role of natural resources, market size, government policy, institutions, and political instability. The World Economy, 29(1), 63-77.

Azam, M., \& Khattak, Naeem-ur-Rehman. (2009). Social and political factors effects on foreign direct investment in Pakistan (1971-2005). Journal of Research, 25(1), 46-50.

Barro, R.J., \& Sala-i-Martin, X. (1995). Technological diffusion, convergence, and growth. National Bureau of Economics and Research, Working Paper 5151, 1-27

Belloumi, M., \& Alshehry, A. (2018). The impacts of domestic and foreign direct investments on economic growth in Saudi Arabia' Economies, 6(1), 1-17.

Blalock, G., \& Gertler, P. J. (2009). How firm capabilities affect who benefits from foreign technology. Journal of Development Economics, 90(2), 192-199.

Blomstrm, M., \& Kokko, A. (2003). Human capital and inward FDI. Stockholm School of Economics, Working Paper 167.

Borensztein, E., De Gregorio, J., \& Lee, Jong-Wha. (1998). How does foreign direct investment affect economic growth'? Journal of International Economics, 45(1), 115-135.

Bosworth, B.P., \& Collins, S.M. (1999). Capital flows to developing economies: Implications for saving and investment. Brookings Papers on Economic Activity, 30(1), 143-180.

Chakraborty, C., \& Basu, P. (2002). Foreign direct investment and growth in India: A cointegration approach. Applied Economics, 34(1), 1061-73. doi.org/10.1080/00036840110074079

Choi, Y.J., \& Baek, J. (2017). Does FDI really matter to economic growth in India?' Economies, 5(20), 1-9. doi.org/10.3390/economies5020020 
De Mello, Luzi R. (1997). Foreign direct investment-led growth: Evidence from time series and panel data. Oxford Economic Papers, 51(1), 133-51.

Dorozynska, A., \& Dorozynska, T. (2014). The role of human capital in attracting FDI: The case of the LODZ region. XCII, 221-242.

Eller, M., Haiss, P.R., \& Steiner, K. (2005). Foreign direct investment in the financial sector: The engine of growth for Central and Eastern Europe?' Europa Institute Working Paper No. 69. Vienna: Vienna University of Economics and Business Administration.

Engle, R.F., \& Granger, C.W.J. (1987). Co-integration and error correction: representation, estimation, and testing. Econometrica, 55(2), 251-276.

Erramilli, M.K., \& D’Souza, D.E. (1995). Uncertainty and foreign direct investment: The role of moderators. International Marketing Review, 12(3), 47-60.

Farole, T., \& Winkler, D. (2015). The role of foreign firm characteristics, absorptive capacity and the institutional framework for FDI spillovers. Journal of Banking and Financial Economics, 1(3), 77-112.

Girma, S., \& Gorg, H. (2005). Foreign direct investment, spillovers and absorptive capacity: Evidence from quantile regressions. Bundesbank Discussion Paper Series 1: Economic Studies No 3/2005. https://papers.ssrn.com/sol3/papers.cfm?abstract_id=2785099

Government of Pakistan Finance Division Poverty Reduction Strategy Paper-II. http://www .finance.gov.pk/poverty/prsp-ii.pdf

Hsu, J. \& Tiao, Yu-En. (2015). Patent rights protection and foreign direct investment in Asian countries. Economic Modelling, 44, 1-6.

Hussain, M.E., \& Haque, M. (2016). Foreign direct investment, trade, and economic growth: An empirical analysis of Bangladesh. Economies, 4(7), 1-14. doi:10.3390/economies4020007

Iqbal, N., Ahmad, N., Haider, Z., \& Anwar, S. (2014). Impact of foreign direct investment (FDI) on GDP: A case study from Pakistan. International Letters of Social and Humanistic Sciences, 16, 73-80.

Johansen, S. (1991). Estimation and hypothesis testing of cointegration vectors in Gaussian vector autoregressive models. Econometrica, 59(6), 1551-1580.

Khan, G.S., \& Mitra, P. (2014). A causal linkage between FDI inflows with select macroeconomic variables in India - An econometric analysis. Journal of Economics and Finance, 5(5), 124-133.

Khordagui, N., \& Saleh, G. (2016). Absorptive capacity factors that mediate foreign direct investment spillovers: A sector-level analysis from emerging economies. International Journal of Business and Globalization, 16(2), 188-201.

Kim, Hyuk-Hwang., Lee, H., \& Lee, J. (2015). Technology diffusion and host-country productivity in south-south FDI flows. Japan and the world Economy, 33, 1-10.

Kinishita, Y., \& Chia-Hui, Lu. (2006). On the role of absorptive capacity: FDI matters to growth. William Davidson Institute Working Paper Number 845.

Kinoshita, Y. (2000). R\&D and technology spillovers via FDI: Innovation and absorptive capacity. CEPR Discussion Paper DP 2775.

Krogstrup, S., \& Matar, L. (2005). Foreign direct investment, absorptive capacity and growth in the Arab World. HEI Working Paper No: 02/2005, Graduate Institute of International Studies, Geneva, pp. 1-23.

Liu, X., Burridge, P., \& Sinclair, P.J.N. (2002). Relationships between economic growth, foreign direct investment and trade: Evidence from China. Applied Economics, 34(1), 1433-40. doi.org/10.1080/00036840110100835 
MacKinnon, J.G. (1996). Numerical distribution functions for unit root and cointegration tests. Journal of Applied Econometrics, 11(6), 601-618.

Markusen, J.R. (1995). The boundaries of multinational enterprizes and theory of international trade. The Journal of Economic Perspectives, 9(2), 169-189.

Moses, EC. (2011). Oil and nonoil FDI and economic growth in Nigeria. Journal of Emerging Trends in Economics and Management Sciences, 2, 333-43.

Noorbakhsh, F., Paloni, A., \& Yousif, A. (2001). Human capital and FDI inflow to developing countries: New empirical evidence. World Development, 2(9), 1593-1610.

Oyakhilomen, A., \& Zibah, R.G. (2014). Agricultural production and economic growth in Nigeria: Implication for rural poverty alleviation. Quarterly Journal of International Agriculture, 53(3), 207-223.

Pesaran, M.H., Shin, Y., \& Smith, R.J. (2001). Bounds testing approaches to the analysis of level relationships. Journal of Applied Econometrics, 16(3), 289-326.

Phillips, P.C.B., \& Hansen, B.E. (1990). Statistical inference in instrumental variables regression with I(1) processes. The Review of Economic Studies, 57(1), 99-125.

Ridzuan, A.R., Ismail, N.A., \& Hamat, A.F.C.H. (2017). Does foreign direct investment successfully lead to sustainable development in Singapore? Economies, 5(29), 2-20. doi:10.3390/economies5030029

Romer, P.M. (1990). Human capital and growth: theory and evidence. National Bureau of Economic Research Working Paper No. 3173.

Seyoum, B. (1996). The impact of intellectual property rights on foreign direct investment. The Columbia Journal of World Business, 31(1), 50-59.

Shabaz, A., Javed, A., Sattar, A. \& Tanzeela, S. (2011). Impact of terrorism on foreign direct investment in Pakistan. Archives of Business Research, 1(1), 1-7.

Shamsub, H. (2014). Interrelationships between inward FDI and indigenous innovation in developing economies. Global Business and Economics Review, 16(3), 296-309.

Tintin, C. (2012). Does foreign direct investment spur economic growth and development? A comparative study. Paper presented at The 14th Annual European Trade Study Group Conference, Leuven, Belgium, September 13-15.

World Bank World Development Indicators. (2018). The World Bank, World Development Indicators' Retrieved from https://datacatalog.worldbank.org/dataset/worlddevelopment-indicators

Wu, Jyun-Li., \& Hsu, Chih-Chiang. (2012). Foreign direct investment and income inequality: Does the relationship vary with absorptive capacity. Economic Modeling, 29(6), 2183-2189. 


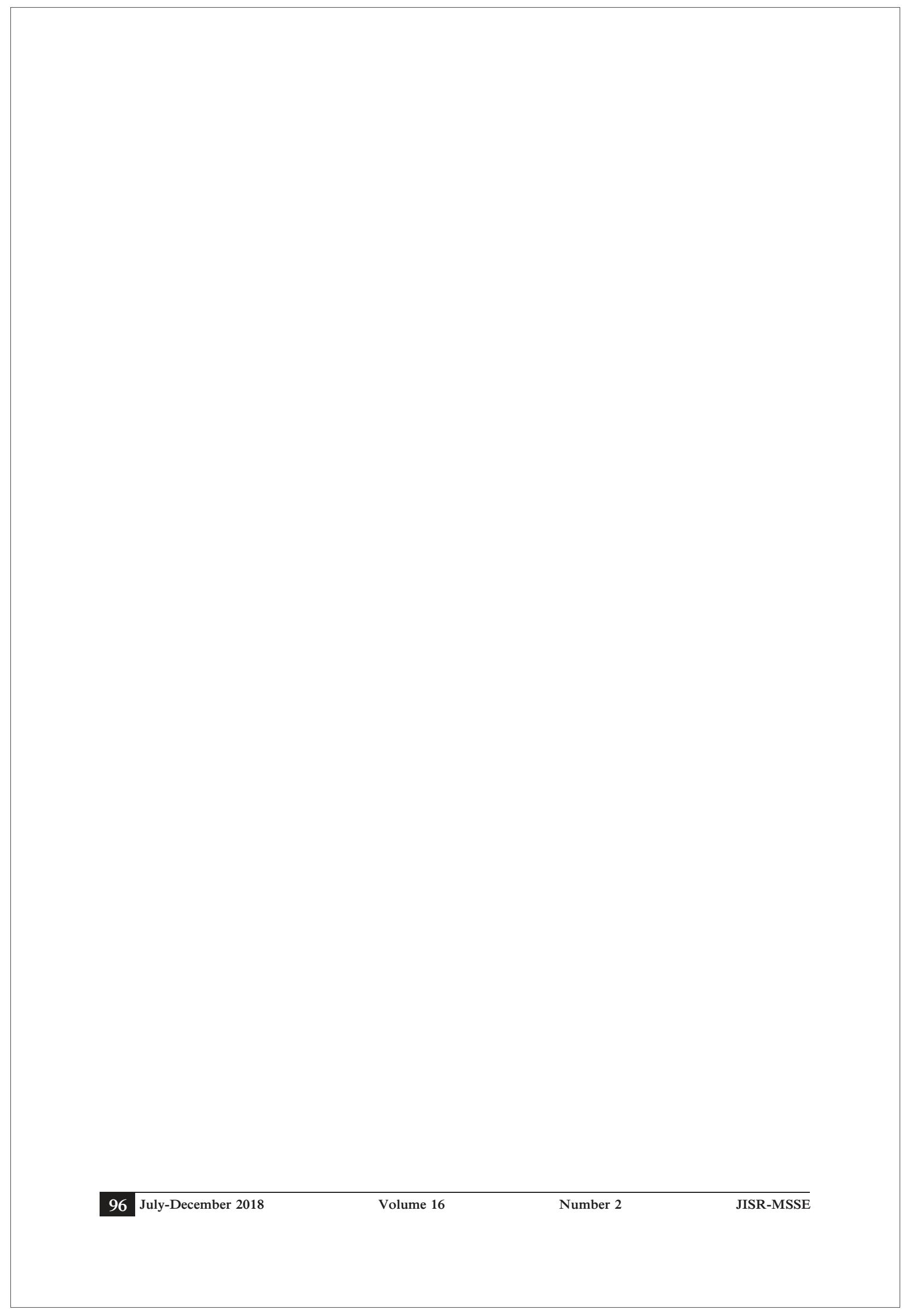

